\title{
Pemulihan Kerusakan Jaringan Hati Mencit yang Diberi Ekstrak Butanol Buah Tua Mahkota Dewa
}

\author{
Arif Soeksmanto \\ Puslit Bioteknologi - LIPI, Jl. Raya Bogor Km. 46 Cibinong 16911 \\ Diterima 11-12-2006 Disetujui 15-09-2007
}

\begin{abstract}
Mahkota dewa (Phaleria macrocarpa [Scheff.] Boerl.) is an Indonesians traditional medicinal plant used to treat various diseases, such as diabetes mellitus, hemorrhoid, impotency and cancer. Almost all parts of the plants can be used as traditional medicine, but if directly consumed, it can cause swollen, sprue, numb at tongue, fever, even unconsciousness. This research was carried out to find out recovery of liver tissue damage of mice administered intraperitoneally with subchronic dosage of butanol extract $170 \mathrm{mg} / \mathrm{kg}$ body weight. Observation on first week showed that there is light degeneration (vacuolization) which is getting better on second week and apparently normal on forth week.
\end{abstract}

Keywords: liver, mahkota dewa, Phaleria macrocarpa, vacuolization.

\section{PENDAHULUAN}

Tumbuhan mahkota dewa (Phaleria macrocarpa [Scheff.] Boerl.) termasuk suku Thymelaceae, yaitu sejenis tumbuhan perdu yang tumbuh dari dataran rendah hingga ketinggian 1.200 meter di atas permukaan laut (Burkill 1966). Tumbuhan ini bentuknya sangat indah dengan buah yang berwarna merah marun, karena itu banyak orang memeliharanya sebagai tanaman hias. Selain itu, pembudidayaannya tidak terlalu sulit, dapat diperbanyak dengan cara mencangkok (vegetatif) maupun menggunakan biji (generatif). Buahnya dapat dimakan, tetapi bijinya mengandung racun (Eisai Indonesia 1986). Bahkan, tumbuhan mahkota dewa dapat tumbuh hingga puluhan tahun (Harmanto 2002).

Akhir-akhir ini, tumbuhan mahkota dewa menjadi sangat populer dikalangan masyarakat, karena dipercaya dapat digunakan untuk mengatasi berbagai macam penyakit. Daun tumbuhan ini menurut Gotawa et al, (1999) mengandung alkaloid, saponin, dan polifenol. Sedangkan menurut Sulistiyani et al, (2006) daunnya juga mengandung alkaloid, senyawa fenolik, saponin dan triterpenoid/steroid. Senyawa saponin ini bersifat menurunkan tegangan permukaan, ditemukan di dalam struktur triterpenoid dan saponin sebagai struktur aglikonnya. Kedua senyawa tersebut mempunyai efek anti inflamasi, analgesik, dan sitotoksik (De Padua et al, 1999). Daun tumbuhan mahkota dewa sering direbus untuk menyembuhkan penyakit lemah syahwat, disentri, alergi, dan tumor (Harmanto 2002).

Buahnya berbentuk bulat dengan ukuran bervariasi mulai dari sebesar bola pingpong sampai sebesar buah apel, dengan ketebalan kulit antara 0,1-0,5 mm. Buah mahkota dewa dapat digunakan untuk mengobati flu, rematik, paru-paru, sirosis hati sampai kanker (Harmanto 2002). Buah mahkota dewa menurut Sumastuti \& Sonlimar (2002) mengandung flavonoid, saponin, alkaloid, terpenoid dan tanin. Ekstrak etanol daging buahnya menghasilkan kadar flavonoid yang tinggi (Anni et al, 2003). Sedangkan di dalam kulit buah mahkota dewa terkandung senyawa alkaloid, saponin, dan flavonoid (Gotawa et al, 1999). Selain itu batangnya yang bergetah untuk mengobati penyakit kanker tulang, bahkan bijinya yang beracunpun digunakan sebagai obat luar untuk mengobati penyakit kulit. Mungkin hanya akar dan bunganya saja yang jarang dipergunakan sebagai obat (Harmanto 2003).

Tumbuhan mahkota dewa yang berkhasiat sebagai obat dan berpotensi sebagai racun, membuatnya dinamakan sebagai simalakama. Menurut Harmanto (2003) bila mengkonsumsi buah mahkota dewa secara langsung dapat menyebabkan bengkak, sariawan, mati rasa pada lidah, kaku, demam, bahkan dapat menyebabkan pingsan. Oleh karena itu perlu diketahui tingkat keamanan dalam mengkonsumsi bagian-bagian dari tumbuhan ini. Terutama pada hati yang menjadi organ utama dalam menghadapi bahan beracun yang masuk ke dalam tubuh. 
Hati merupakan organ tubuh yang paling besar dengan berat sekitar $2,5 \%$ berat badan normal. Tersusun dari unit-unit fungsional acinus yang tampak seperti kelompok-kelompok parenkhim. Meskipun umumnya terjadi variasi dalam species, tetapi struktur penting dan gambaran fungsional pada seluruh species diperkirakan sama (Kelly 1985). Unit-unit fungsional tersebut menyediakan nutrisi secara rutin bagi triliunan sel-sel di dalam tubuh. Prosesnya dilakukan oleh selsel parenkhim, hepatosit dan sel-sel Kupffer yang akan mengubah nutrien ke dalam bentuk-bentuk biokimia yang layak untuk diabsorbsi oleh sel, agar dapat menjalankan fungsinya. Nutrisi seperti vitamin, mineral, asam amino, akan diubah menjadi bentuk-bentuk yang sesuai untuk disimpan dan ditranspor melalui aliran darah atau digunakan untuk metabolisme seluler. Bila hati tidak dapat mengaktifkan nutrisi ke dalam bentuk bioaktif, maka bahan-bahan tersebut tidak dapat digunakan dan mungkin menjadi racun (mildly toxic). Contohnya seperti karbontetraklorida $\left(\mathrm{CCl}_{4}\right)$ yang masuk ke dalam tubuh akan dimetabolisme oleh retikulum endoplasma menjadi radikal triklorometil $\left(\mathrm{CCl}_{3}{ }^{\circ}\right)$. Kemudian dengan adanya oksigen maka $\mathrm{CCl}_{3}{ }^{\circ}$ akan dibentuk menjadi radikal triklorometil dioksida $\left(\mathrm{CCl}_{3} \mathrm{O}_{2}^{\circ}\right)$ yang lebih reaktif.

Sementara nutrisi tersebut diperoleh dari aliran darah vena saluran pencernaan yang mengandung molekul-molekul dengan berat molekul kecil hasil pencernaan, ditambah produk-produk metabolik mikroflora usus. Proses yang sangat berat tersebut setidaknya membutuhkan $12-20 \%$ dari total energi tubuh dan energi itu harus dibangkitkan dari sel-sel hati sendiri (Zakim 1985). Karena itu hati menghasilkan carnitine dari lysine dan nutrisi lainnya. Carnitine ini diketahui sebagai bionutrisi yang mengantarkan lemak ke dalam mitokhondria untuk memperbaharui $90 \%$ bioenergi ATP guna mendukung kehidupan pada tingkat seluler. Kerja otot jantung yang merupakan organ utama tubuh, sangat sensitif terhadap kekurangan carnitine.

Hati juga menjalankan berbagai fungsi-fungsi penting, seperti pembentukan dan ekskresi empedu. Pada manusia, hati mengekskresikan sekitar satu liter cairan empedu tiap hari. Cairan tersebut terdiri dari $97 \%$ air dan sisanya berupa elektrolit, garam empedu, fosfolipid, kolesterol, serta pigmen empedu (terutama bilirubin terkonjugasi). Cairan empedu ini akan dialirkan melalui saluran empedu, untuk disimpan dalam kantung empedu atau dikeluarkan ke dalam usus halus sesuai kebutuhan. Garam-garam empedu berfungsi untuk mengemulsi lemak dan vitamin yang larut dalam lemak (A, D, E, dan K) agar dapat diabsorbsi. Selain itu juga memindahkan racun yang larut dalam lemak ke dalam garam-garam empedu, untuk kemudian di dalam usus campuran racun dan kotoran empedu dapat ekskresikan melalui feces.

Hati juga merubah hormon tiroksin tiroid menjadi tri-iodotironin yang lebih aktif. Bila konversi tiroksin tiroid ke tri-iodotironin tidak memadai, maka hati akan kekurangan energi, sehingga menyebabkan hypothyroidism, kelelahan kronik, penurunan berat badan, pelemahan ingatan dan banyak permasalahan lainnya. Hati juga menciptakan Glucose Tolerance Factor (GFT) dari kromium, niasin dan mungkin glutathione. GFT ini diperlukan insulin dalam mengatur kadar gula darah, sehingga sangat penting perannya dalam memfasilitasi masuknya asam amino ke dalam sel-sel otot. Merombak hormon setelah selesai menjalankan fungsinya pada sel target, misalnya bila insulin tidak cepat dirombak, maka tubuh akan mengalami hypoglikemia.

Aspek penting lainnya adalah mendetoksifikasi berbagai macam racun senobiotika di dalam tubuh, seperti buangan metabolik, alkohol, residu insektisida, obat-obatan atau bahan-bahan kimia berbahaya lainnya. Proses detoksifikasi ini dilakukan oleh enzim hidroksilasi mikrosomal hepatik di retikulum endoplasmik halus dari periacinar, melalui proses oksidasi, reduksi maupun hidrolisis. Menurut Rappaport (1963), biasanya enzim-enzim hidroksilasi mikrosomal terkonsentrasi pada hepatosit periacinar dengan konsentrasi tertinggi pada daerah periacinar. Sistem ini akan mengkonversi senyawa hidrofobik (larut dalam lemak) yang secara alami sulit dieliminasi oleh tubuh, menjadi senyawa hidrofilik (larut dalam air) agar dapat diekskresi ke dalam empedu atau urin. Prosesnya dengan mengubah senyawa polar menjadi molekulmolekul atau modifikasi lainnya, kemudian digabungkan dengan senyawa kimia lain sehingga dapat larut dalam air. Ironisnya dalam proses detoksifikasi tersebut, hati terkadang justru merubah bahan berbahaya menjadi lebih beracun dan merusak sel-selnya sendiri (Hardy 1983). Contohnya karbontetraklorida yang dapat menyebabkan terjadinya kerusakan struktur hepatosit dengan rentang mulai pembengkakan seluler seperti 
lipidosis sampai nekrosis. Pada kasus keracunan berat, kegagalan fungsi hati umumnya menyebabkan kematian dalam 12-24 jam (Huxtable 1988). Selain mendetoksifikasi bahan racun, hati juga memiliki sel Kuppfer pada dinding sinusoid hati. Sel ini memiliki kemampuan fagositosis yang sangat besar, sehingga mampu membersihkan hampir seluruh kuman yang ada dalam vena porta sebelum darah menyebar melewati seluruh sinusoid (Huxtable 1988).

Tumbuhan mahkota dewa sebagai bahan obat tradisional, semakin populer dengan adanya buku mengenai pengalaman pribadi, dari orang-orang yang berhasil sembuh karena mahkota dewa. Hal tersebut menyebabkan banyak orang yang tertarik untuk mengkonsumsinya sebagai obat tradisional, baik secara tunggal maupun dicampur dengan obat-obatan tradisional lainnya. Kurangnya pengetahuan masyarakat mengenai daya racun tumbuhan mahkota dewa, dikhawatirkan akan dikonsumsi jumlah besar. Sehubungan dengan hal tersebut, maka penelitian ini akan mengamati kemungkinan efek racun dan pemulihan jaringan hati mencit (Mus musculus) yang diberi ekstrak tumbuhan mahkota dewa, khususnya ekstrak butanol.

\section{BAHAN DAN METODE}

Pengujian pengaruh ekstrak butanol dari buah tua mahkota dewa dilakukan di Laboratorium Kimia Bahan Alam, Pusat Penelitian Bioteknologi-LIPI, Jalan Raya Bogor Km 46, Cibinong. Hewan percobaan yang digunakan adalah mencit (Mus musculus) jantan yang berumur \pm 2 bulan. Mencit tersebut di tempatkan dalam 4 buah bak plastik yang masing-masing berisi 5 ekor mencit. Selanjutnya, bak plastik tersebut ditutup dengan kawat serta diberi pakan dan minum secara ad libitum.

Ekstrak butanol diperoleh dengan cara mengekstraksi buah tua mahkota dewa menggunakan etanol, kemudian dipartisi dengan etilasetat-air (1:1). Lapisan air yang diperoleh selanjutnya diekstraksi kembali dengan menggunakan pelarut butanol untuk memisahkan lapisan air dan butanol. Akhirnya lapisan butanol yang diperoleh, kemudian diuapkan hingga kering dan dilarutkan dalam garam fisiologis dengan bantuan alat sonikator.

Ekstrak butanol yang diperoleh dari buah tua mahkota dewa tersebut selanjutnya diberikan melalui penyuntikan secara intraperitoneal pada mencit dengan dosis tunggal sebesar $170 \mathrm{mg} / \mathrm{kg}$ berat badan mencit atau setara dengan dosis manusia $944,45 \mathrm{mg} / 50 \mathrm{~kg}$. Pengamatan dilakukan dengan mengamati perkembangan histologi dari jaringan hati mencit selama 4 minggu.

\section{HASIL DAN PEMBAHASAN}

Berdasarkan pengamatan yang dilakukan terhadap pemberian dosis ekstrak butanol buah tua mahkota dewa sebesar $170 \mathrm{mg} / \mathrm{kg}$ berat badan, tidak ditemukankan adanya perubahan perilaku umum, selera makan maupun perilaku lainnya. Sedangkan pada pengamatan histologi organ hati yang dilakukan, hanya ditemukan adanya vakuolisasi dan gambaran terjadinya proses mitosis pada minggu pertama. Hal ini menunjukkan bahwa pemberian dosis sebesar $170 \mathrm{mg} /$ $\mathrm{kg}$ berat badan kurang berpengaruh terhadap jaringan hati (Gambar 1 dan 2).

Terjadinya vakuolisasi mungkin disebabkan oleh terganggunya hepatosit dalam mengubah nutrisi ke dalam bentuk-bentuk biokimia yang layak untuk diabsorbsi oleh sel. Menurut Zakim (1985), kebutuhan

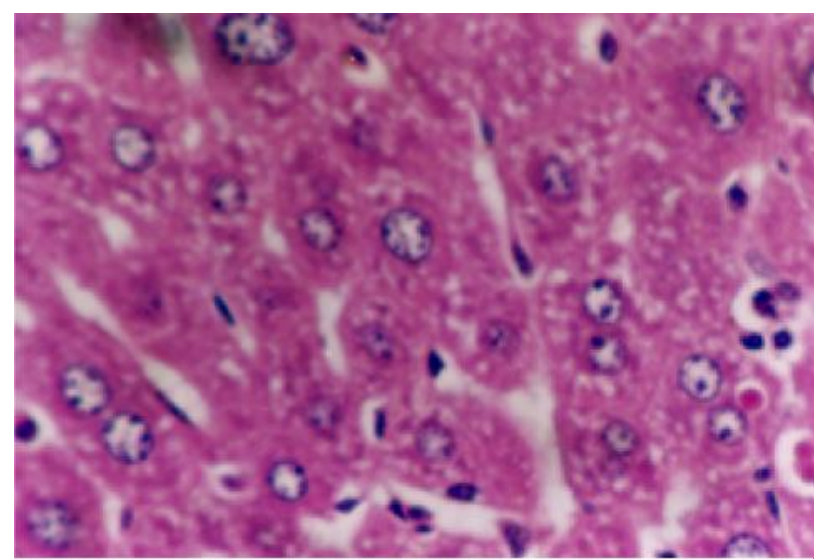

Gambar 1. Potongan melintang hati mencit kontrol yang tidak diberi ekstrak butanol buah tua tanaman mahkota

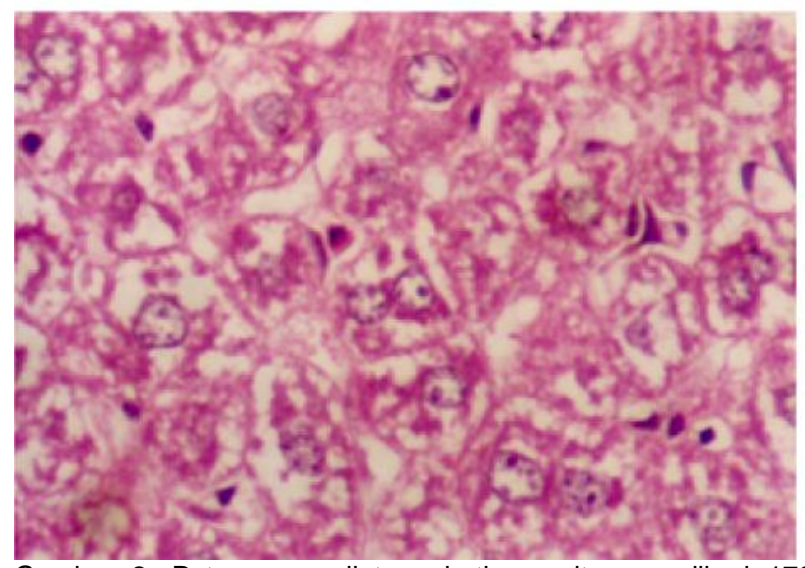

Gambar 2. Potongan melintang hati mencit yang diberi 170 $\mathrm{mg} / \mathrm{kg}$ bb ekstrak butanol buah tua tanaman mahkota dewa yang diamati pada minggu pertama 
bahan energi sel-sel tubuh berasal dari hati, yang proses pembentukkannya membutuhkan $12-20 \%$ dari total energi tubuh dan energi itu harus dibangkitkan dari sel-sel hati sendiri. Terganggunya hepatosit akan memacu hati untuk melakukan penyimpanan triglyserida besar-besaran untuk energi metabolisme. Akibatnya, hati tidak mampu memprosesnya sehingga lemak akan terakumulasi dan menimbulkan pembengkakan sel maupun degenerasi seluler.

Pada kondisi ini, hati masih dapat mempertahankan fungsi normalnya, sekalipun hanya dengan 10-12\% unit fungsional yang normal (Arias et al, 1982). Meskipun demikian pada keadaan ekstrem, sel yang membengkak dapat menghalangi aliran darah maupun empedu, sehingga mengakibatkan terganggunya fungsi hati dan payah hati terjadi. Pada kasus berat dapat menyebabkan terjadinya hepatomegali (pembesaran hati), hati berwarna kuning/ bronze dan berminyak (Huxtable 1988), dan selanjutnya menyebabkan kematian sel yang dapat diketahui melalui adanya perubahan-perubahan pada sitoplasma dan inti selnya (Evans \& Butler 1993). Menurut Huxtable (1988), kerusakan struktur hepatosit dimulai dari pembengkakan seluler seperti lipidosis sampai nekrosis, sedangkan pada kasus keracunan berat akan menyebabkan terjadinya kegagalan fungsi hati yang menyebabkan kematian dalam 12-24 jam.

Menurut Sani et al, (1998), pemberian $1 \mathrm{mg} / \mathrm{ekor}$ ekstrak daun babandotan pada tikus dapat menyebabkan kematian dalam waktu 3 hari, dengan kerusakan jaringan terdiri dari vakuolisasi, anisokariosis, megalositosis, dan infiltrasi sel-sel mononuklear. Dalam penelitian ini, meskipun pemberian dosis sebesar 170 $\mathrm{mg} / \mathrm{kg}$ berat badan tampak terbentuk vakuola, tetapi pada umumnya tidak mengganggu fungsi hati. Selain memiliki enzim-enzim hidroksilasi mikrosomal, daerah periacinar juga memiliki enzim-enzim pembentuk glikogen dan protein, sehingga merupakan daerah aktif untuk proses sitognesis (Rappaport 1973). Oleh karena itu, hati dapat memperbaiki sel-selnya yang rusak melalui pembelahan mitotik dan tampak normal pada pengamatan berikutnya (Gambar 34 ).

Menurut Arias et al, (1982), hati merupakan organ yang sangat luar biasa dalam mempertahankan fungsinya, sehingga masih dapat mempertahankan
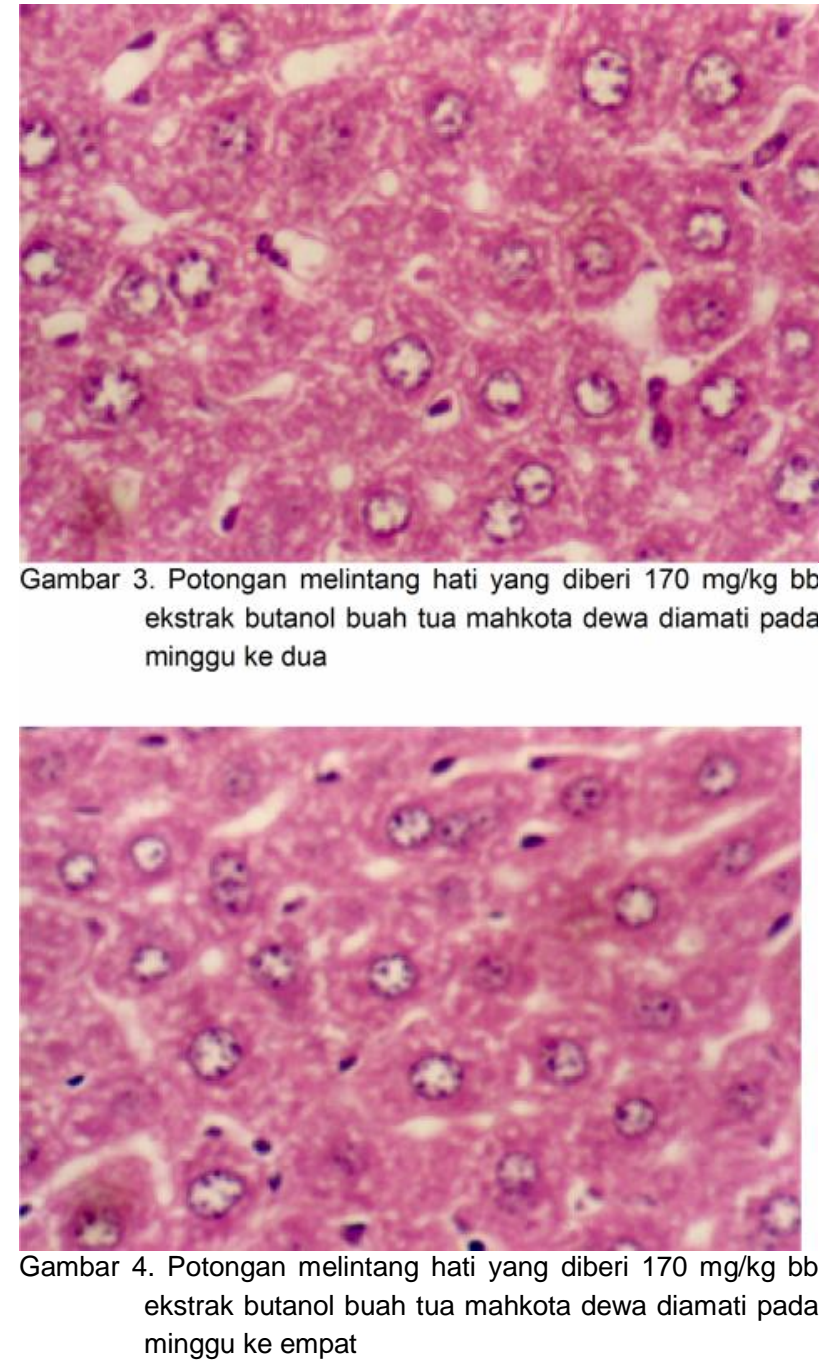

fungsi normalnya meskipun hanya dengan $10-12 \%$ unit fungsional yang normal. Selain itu, umumnya bahanbahan asing yang masuk ke dalam tubuh, dapat didetoksifikasi oleh enzim mikrosomal hepatik di retikulum endoplasmik halus dari periacinar, melalui proses oksidasi, reduksi maupun hidrolisis. Sistem ini akan mengkonversi senyawa hidrofobik (larut dalam lemak) yang sulit dieliminasi oleh tubuh, menjadi senyawa hidrofilik (larut dalam air). Kemudian secara simultan, bahan-bahan berbahaya tersebut diekskresi ke dalam empedu atau urin yang dikeluarkan setiap hari (Aldridge et al, 1993). Kemampuan untuk memproteksi kerusakan akibat bahan kimia di atas, umumnya dimiliki oleh semua jenis mamalia, meskipun kemampuan melawan partikel-partikel bahan tersebut bervariasi di antara spesies, terutama dalam memindahkan 1 gugus etil melalui oksidasi mikrosomal (Donninger 1971). 


\section{KESIMPULAN}

Dosis tunggal ekstrak butanol buah tua mahkota dewa sebesar $170 \mathrm{mg} / \mathrm{kg}$ berat badan tidak mengganggu histologi hati mencit percobaan.

\section{UCAPAN TERIMA KASIH}

Ucapan terimakasih penulis disampaikan kepada Dr. Padmono Citroreksoko dan staf Laboratorium Kimia Bahan Alam, Pusat Penelitian Bioteknologi-LIPI, Jalan Raya Bogor Km 46, Cibinong atas penyediaan ekstrak tumbuhan mahkota dewa yang digunakan dalam penelitian ini.

\section{DAFTAR PUSTAKA}

Aldridge, W.N. 1993. The biochemical principles of toxicology. Di dalam: Anderson, D. \& Conning, D.M. (eds). Experimental Toxicology; The Basic Issue. $2^{\text {nd }}$ edition. Bodmin: Hartnoll Ltd. h. 56-81

Anni, S., Nurmawan, D., Alfiani, F., Hertiani, T. 2003. Daya antioksidan dan kadar flavonoid hasil estrak etanol-air daging buah mahkota dewa (Phaleria macrocarpa (Scheff.) Boerl.). Buletin Penalaran Mahasiwa UGM.

Arias, I., Popper, H., Schaefer, D., \& Shafritz, D.A. 1982. The Liver, Biology and Patho- Biology. New York: Reven Press.

Burkill, I.H. 1966. A Dictionary of the Economic Products of the Malay Penninsula. Vol. II. Kuala Lumpur: Ministry of Agriculture and Co-operatives. h. 1732.

De Padua, L.S., Bunyapraphatsara, N. \& Lemmens, R.H.M.S. 1999. Plant Resources of South East Asia. Medical and Poisonous Plants. Leiden, the Netherlands, Printed in Bogor Indonesia (PROSEA): Backhuys Publishers. h. 36.

Donninger, C. 1971. Species specificity of phosphate trimester anticholin-esterase. Bull. WHO 44: 265.

Eisai Indonesia. 1986. Index Tumbuh-Tumbuhan Obat Indonesia. P.T. Eisai Indonesia. h. 84.

Evans, J.G. \& W.H. Butler. 1993 Histopathology in Safety Evaluation. Anderson, D. \& Conning, D.M. (eds). Experimental Toxicology; The Basic Issue, $2^{\text {nd }}$ edition. Bodmin: Hartnoll Ltd. h. 119.
Gotawa, I.B.I., Sugiarto, S., Nurhadi, M., Widiyastuti, Y., Wahyono, S., Prapti, I.J. 1999. Inventaris Tanaman Obat Indonesia. Jilid V. Jakarta: Departemen Kes. Badan Penelitian dan Pengembangan Kesehatan. h. 147-148.

Hardy, R.M. 1983. Disease of the liver. Di dalam: Ettinger, S.J. (ed). Textbook of Veterinary Internal Medicine, Vol. 2. Philadelphia: W.B. Saunders Co. h. 1372.

Harmanto, N. 2002. Sehat Dengan Ramuan Tradisional Mahkota Dewa. Cetakan ke empat. Tangerang: PT. Agromedia Pustaka.

Harmanto, N. 2003. Conquering Disease in Unison with Mahkota Dewa (Phaleria macrocarpa). First editon. Jakarta: P.T. Mahkotadewa Indonesiah.

Huxtable, C.R.R. 1988. The urinary system. Di dalam: Robinson, W.F. \& Huxtable, C.R.R. (eds). Clinicopathologic Principles for Veterinary Medicine. First Published. Cambridge University Press. h. 216.

Kelly, W.R. 1985. The liver. Di dalam: Jubb, K.V.F., Kennedy, P.C. \& Palmer, N. (eds). Pathology of Domestic Animals. $3^{\text {rd }}$ edition. Orlando: Academic Press. h. 239.

Rappaport, M.A. 1963. Acinar units and the physiopathology of the liver. In: The Liver Morphology, Biochemistry, Physiology, Vol. I. Ch. Rouiller (ed). New York: Academic Press. p. 265.

Rappaport, M.A. 1973. The microcirculatory hepatic unit. Microvascular Research 6: 212-218.

Sani, Y., Bustami, S., \& Girindra, A. 1998. Hepatotoksisitas ekstrak daun babadotan (Ageratum conyzoides) pada tikus percobaan. J. IImu Ternak \& Veteriner 3(1): 63.

Sulistiyani, Sofianti, D., \& Purwakusumah, E.D. 2006. Khasiat antioksidan ekstrak daun mahkota dewa (Phaleria macrocarpa (Scheff.) Boerl.) pada umur yang berbeda. Prosiding Seminar Nasional Tumbuhan Obat Indonesia $X X I X$. Fakultas Kedokteran Universitas Sebelas Maret Surakarta, Solo, 24-25 Maret 2006.

Sumastuti, R. \& Sonlimar, M. 2002. Efek sitotoksik ekstrak buah dan daun mahkota dewa [Phaleria macrocarpa (Scheff) Boerl.] terhadap sel Hela. Medika. No 12: 773-777.

Zakim, O. 1985. Pathophysiology of liver disease. Di dalam: Smith, L.M. \& Their, S.O. (eds). Pathophysiology: The Biological Principles of Disease. $2^{\text {nd }}$ edition. Philadelphia: W.B. Saunders Co. h. 799. 